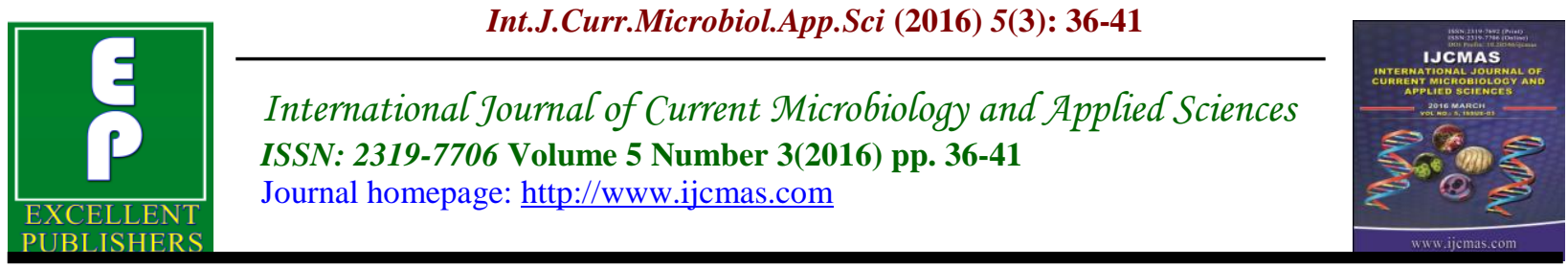

Original Research Article

http://dx.doi.org/10.20546/ijcmas.2016.503.005

\title{
Evaluation of Total Suspended Particles in Ambient Air of Small Scale Industries in Kaduna Metropolis
}

\author{
R.O. Esekhagbe ${ }^{1}$, G.B. Onwumere ${ }^{2}$ and P.A.Vantsawa ${ }^{2 *}$ \\ ${ }^{1}$ National Productivity Centre Kaduna, Nigeria \\ ${ }^{2}$ Department of Biological Sciences, Nigerian Defence Academy, Kaduna, Nigeria \\ *Corresponding author
}

\begin{abstract}
A B S T R A C T
Keywords

Suspended

particles,

Season,

Ambient air,

Kaduna.

\section{Article Info}

Accepted:

07 February 2016

Available Online:

10, March 2016

The Total Suspended Particles (TSP) concentration levels were measured in the following Small Scale Industries (SSI): Battery Charging Maintenance (BCM), Welding (W), Smelting (S), Vehicle Spray Paint (VSP). The control site was the Federal Secretariat in Kaduna metropolis. The measurement was done during the wet and dry seasons. The study was conducted in areas where these industries were prevalent whose activities generate particles in ambient air. The sampling was done during working hours using high volume sampling technique. The results for the concentration of the TSP were $0.5554 \mathrm{mg} / \mathrm{kg}, 0.3970 \mathrm{mg} / \mathrm{kg}, 0.3547 \mathrm{mg} / \mathrm{kg}$, $0.3549 \mathrm{mg} / \mathrm{kg}$, and $0.0830 \mathrm{mg} / \mathrm{kg}$ for BCM W, S, VSP, and control respectively. The level of the TSP contamination was higher in the ambient air of the BCM than all the other SSI, while the control recorded the least. The TSP was also higher during the dry season $(0.4748 \mathrm{mg} / \mathrm{kg})$ when compared to the wet season $(0.2694 \mathrm{mg} / \mathrm{kg})$. The study shows that weather and the activities of the SSI contributed nnjr2q increase of TSP. It is recommended that regulatory agencies should monitor the emissions of suspended particles from these industries.
\end{abstract}

\section{Introduction}

The sustainability of life is dependent on the environment since the environment plays important role in the health of many in the world. The quality of air we breathe is determined by the amount of gaseous pollutants and particulate matter. Industrialization and urbanization led to improved roadside accessibility with increased attendant problems from a variety of informal jobs ranging from battery chargers, vulcanizes, auto-electrician and welders (Adefolaju, 1980). The activities of these sectors release pollutants into the air. One of the most useful indicators for the degree of air pollution is suspended particulate matter (SPM) level (Akeredolu, 1989). These suspended particles in the atmosphere are comprised of either solid particles or fine liquid droplets and included in this group are aerosols, smoke fames, dust, fly ash and pollen (USEPA, 2004). 
The bulk of this suspended particle emissions are from human activity which have diameters of less than 100 micros (millionths of a meter) which are known as total suspended particles (TSP). Particles that are less than 10 microns and 2.5 microns are defined as inhalable particles and reparable particles respectively. The exact make up varies with both place and season (Hang, 2002). Total suspended particles have great effect on the health of man. Dominici et al. (2006) noted in their study that it is connected to hospital admissions and premature death. They also explained that it causes corrosion, soiling, damage to vegetation and visibility reduction.

With the increase in number of informal sectors or small- scale industries in Nigeria, which emits pollutants into the atmosphere, thereby compounding the problem of total suspended particles; it is germane to investigate the air around small scale industries in Kaduna metropolis for possible emission of particles.

\section{Materials and Methods}

This study was conducted in Kaduna State, Northern Nigeria. The study examines four groups of small scale industries, namely: Battery Charging Maintenance (BCM), Welders (W), and Smelters (S) and Vehicle Spray Painters (VSP), ) spread across Kaduna Metropolis (Kawo, Ung-Dosa, UngSanusi, Tudun-wada, Kakuri and SaboTasha) as shown in (Figure1). These areas were chosen based on the prevalence of the groups. The control was the State Secretariat annex in Kaduna, Nigeria. Samples were collected during the dry season (November March) and wet season (July - September). Five workshops were selected from each of the groups and ten individuals were sampled from each of these groups.
The samples were collected using SKC sidekick sampling pump 224-50 as recommended by Mueller and Smith, (1991). This was carried out during the working hours. Wastes from these industries were disposed indiscriminately in the premises of the workshops sampled. Some of these shops particularly the BMC were located inside the residential houses while others were in open spaces in between residential houses. Samples were collected and sheltered from any direct rain as recommended by Mueller and Smith, (1991). This was done by filtration on Whatman membrane filters of $25 \mathrm{~mm}$ with a pore size of $3.0 \mu \mathrm{m}$. Sampling was done during working hours and for each sampling, the filter and cassette were humidity-conditioned (equilibrated) in a charged desiccators for $24 \mathrm{hrs}$ and weighed before and after sampling. The amount of TSP collected per volume of air sampled was the difference between the two weights. The Suspended Particulate Matter (SPM) was calculated using this formula.

$\mathrm{SPM}=\mathrm{Wp} / \mathrm{V}$ air,

SPM $=$ Total Suspended Particulate Matter

$\mathrm{Wp}=\mathrm{W} 1-\mathrm{W} 0=$ Weight of particulate matter, where

W1 is the weight of loaded filter and W0 is the weight of unloaded filter.

$\mathrm{V}$ air $=\mathrm{Fr} \times \mathrm{St}=$ volume of air sampled; where Fr is the flow rate and St the sampling time.

The range, mean concentrations, enrichment factors, and variance were calculated for the SPM in different workshops. ANOVA values were compared to show the level of significance of the relationship between the different Artisans and season. 


\section{Results and Discussion}

The total suspended particles in the ambient air of various workshops are presented in Table1. The mean of the TSP in the BCM site, $0.56 \mathrm{mg} / \mathrm{kg}$ was more than all the other sites with the control being the least $0.083 \mathrm{mg} / \mathrm{kg}$. The total suspended particulate matter in air within battery charging maintenance, vehicle spray paint, welding, smelting and the control sites during dry and wet season are presented in Table 2. The concentration of TSP in the various workshops followed a clear seasonal trend. The dry season TSP concentration was in the order of $\mathrm{BCM}>\mathrm{W}>\mathrm{S}>\mathrm{VSP}$, While the wet season concentration followed a reversed trend.

The TSP in the control was significantly lower $(\mathrm{P}<0.05)$ than the TSP in all the other SSI. Conversely, it was observed that the value for BCM was significantly higher $(\mathrm{P}<0.05)$ than the other SSI. The values of the TSP for the BCM was significantly higher $(\mathrm{p}<0.05)$ during dry season than the wet season. While seasonal concentrations did not change for VSP, $\mathrm{S}$ and $\mathrm{W}$ as shown in table 3.

Table.1 Total Suspended Particles in Ambient Air of Various Workshops

\begin{tabular}{llccc}
\hline & $\begin{array}{l}\text { Minimum } \\
(\mathbf{m g} / \mathbf{k g})\end{array}$ & Maximum(mg/kg) & $\begin{array}{c}\text { Mean } \\
(\mathbf{m g} / \mathbf{k g})\end{array}$ & Std. Deviation \\
& & & & \\
\hline Control & 0.0694 & 0.0976 & 0.083085 & \pm 0.0113424 \\
Battery Charging & 0.2353 & 0.9006 & 0.555480 & \pm 0.2848671 \\
Welding & 0.2443 & 0.5689 & 0.397090 & \pm 0.1142775 \\
Smelting & 0.2297 & 0.4884 & 0.354720 & \pm 0.0922034 \\
Vehicle spray paint & 0.2803 & 0.4645 & 0.354390 & \pm 0.0641161 \\
Standard & & & 0.000120 & \\
(NESREA) & & & & \\
\hline
\end{tabular}

Table.2 Total Suspended Particulate Matters in Ambient Air

\begin{tabular}{lllc}
\hline Period & Activities of SSI & Mean $(\mathrm{mg} / \mathrm{kg})$ & Std. Deviation \\
\hline \multirow{5}{*}{ Dry season } & Battery charging & 0.82 & \pm 0.047 \\
& Welding & 0.49 & \pm 0.097 \\
& Smelter shop & 0.44 & \pm 0.053 \\
& Control site & 0.09 & \pm 0.00 \\
& Spray painter & 0.40 & \pm 0.085 \\
\hline & & & \\
& Battery charging & 0.30 & \pm 0.097 \\
& Welding & 0.32 & \pm 0.077 \\
& Smelter & 0.28 & \pm 0.08 \\
& Control site & 0.07 & \pm 0.00 \\
& Spray painter & 0.32 & \pm 0.051 \\
& Standard (NESREA) & 0.000120 & \\
\hline
\end{tabular}


Table.3 Multiple Comparisons of Seasonal Variation

\begin{tabular}{llll}
\hline SSI Activity & SSI Activity & Mean Difference & Std. Error \\
\hline \multirow{4}{*}{ Control } & Battery Charging & $0.4724^{*}$ & .05638 \\
& Welding & $0.3140^{*}$ & .05638 \\
& Smelting & $0.2716^{*}$ & .05638 \\
& Vehicle spray paint & $0.2713^{*}$ & .05638 \\
\hline \multirow{3}{*}{ Battery Charging } & Control & $0.4724^{*}$ & .05638 \\
& Welding & $0.1584^{*}$ & .04883 \\
& Smelting & $0.2008^{*}$ & .04883 \\
& Vehicle spray paint & $0.2011^{*}$ & .04883 \\
\hline \multirow{3}{*}{ Welding } & Control & $0.3140^{*}$ & .05638 \\
& Battery Charging & $0.1584^{*}$ & .04883 \\
& Smelting & 0.0424 & .04883 \\
Smelting & Vehicle spray paint & 0.0427 & .04883 \\
& Control & $0.2716^{*}$ & .05638 \\
& Battery Charging & $0.2008^{*}$ & .04883 \\
& Welding & 0.0424 & .04883 \\
Vehicle spray paint & Vehicle spray paint & 0.0003 & .04883 \\
& Control & $0.2713^{*}$ & .05638 \\
& Battery Charging & $0.2011^{*}$ & .04883 \\
& Welding & 0.0427 & .04883 \\
\hline
\end{tabular}

Based on observed means the error term (Mean Square Error) $=.012$.

$*$. The mean difference is significant at 0.05 levels.

Fig.1 Map showing Sample sites in Kaduna Metropolis

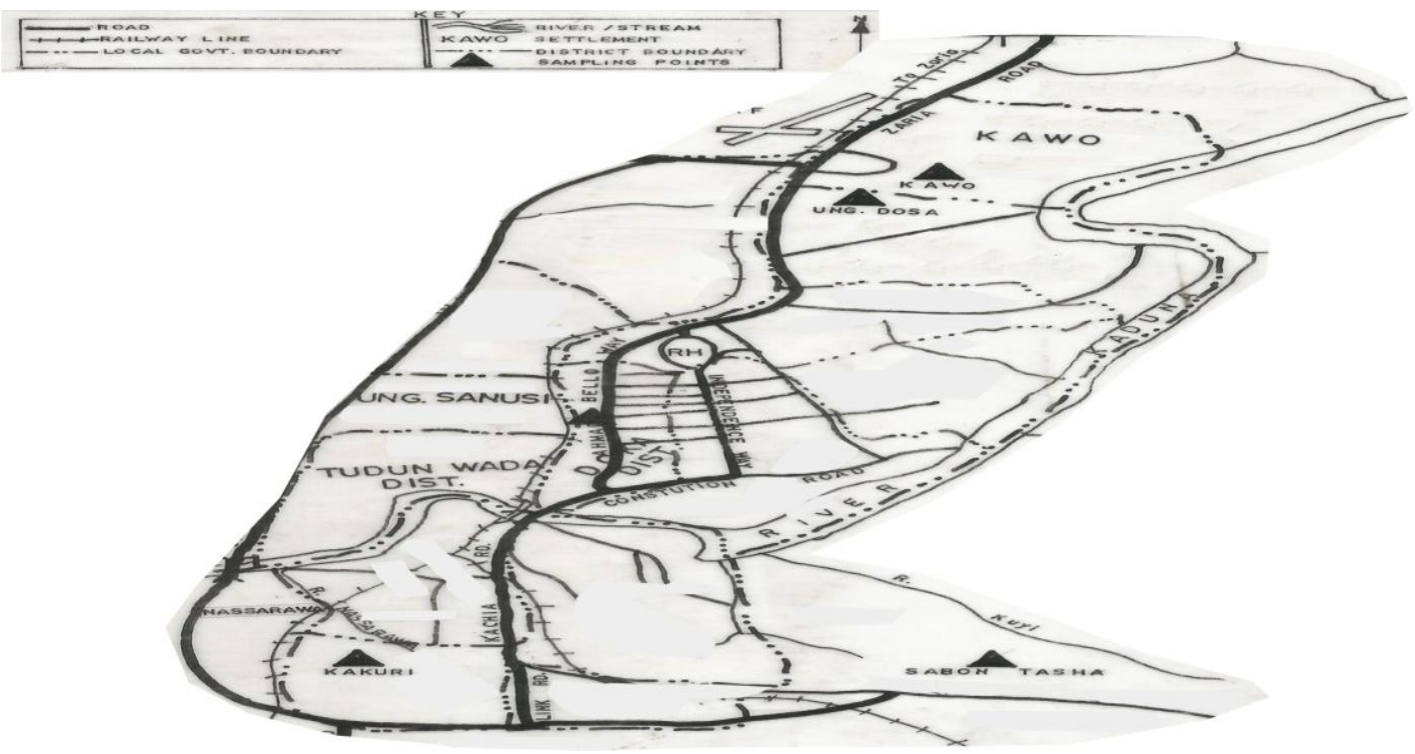


Generally, TSP concentration within all investigated workshops and the control sites exceeded the recommended NESREA standard $(0.0012 \mathrm{mg} / \mathrm{kg})$ for clean air, while only the level within the control site fail within acceptable limit $(0.0025 \mathrm{mg} / \mathrm{kg})$ recommended for Nigeria by NESREA.

All the investigated small-scale industrial activities culminated to an average of at least two fold increases in TSP concentration in air. The effect of BCM, W and $\mathrm{S}$ activities was highly seasonal; the TSP concentration in the air during the dry season was about $80 \%$ more than wet season level within each workshop. The observed TSP level during the wet and dry season which exceeded the World Health Organization ambient air quality standard of $120 \mathrm{mg} / \mathrm{kg}$ and the National Environmental Standards Regulations Agency (NESREA) limits of Nigeria could be attributed to the presence of airborne emissions from these small scale industries (SSI). The concentration of the TSP which was in this order $\mathrm{BCM}>\mathrm{W}>\mathrm{S}>\mathrm{VSP}$ where the $\mathrm{BCM}$ site was more is contrary to the findings of Okuo and Okolo (2011). They observed that the TSP was higher in the welding sites. However, this study corroborates the findings of Yahaya and Sadullah (2006) who reported that TSP was less in open spaces than enclosed spaces. This also agrees with the work of Lee and Hieu (2010). They are of the opinion that it may be due to variations in metrological factors such as humidity and wind where the atmospheric moisture helps the suspended particles to stick to each other and gradually settle down. The results of TSP observed in this study also corroborate the work of Awan et al. (2011), where the TSP value was very high due to industrial and vehicular activities. Karar et al. (2006) also observed that TSP was seasonal with high concentrations in dry season and low concentration in wet season. They noted that road dust automobile traffic may affect the measured particulate level.

This study indicates that the activities of the SSI were the main sources of pollutant in this area.

In conclusion, this study has shown that air around the Small Scale Industries is filled with a lot of particulate matter which clearly exceeded the recommended limits of the regulatory agency (NESREA). It invariably means that the artisans are at risk of respiratory and its attendant problems. It is therefore recommended that the regulatory agencies should monitor the emissions from these industries.

\section{References}

Adefolaju, A.A., 1980. Transport and rural integrated development in proceedings of the National conference on: Inte. Rural Dev. Women Dev., 1: 294-299.

Akeredolu, F. 1989. Atmospheric problems in Nigeria - An overview. Atmospheric Environment, Vol. 23 No. 4, pp. 783-792.

Awan, M..A, Ahmed, S.H., Aslam, M.R., Qazi, I.A. 2011. Determination of total suspended particulate matter and heavy metals in ambient air of four cities of Pakistan. Iranica $J$. Energy Environment, 2(2), 2011, 128 $-132$

Dominici, F., Peng, R.D., Bell, M.I., Pharm, I., McDermott, A., Zeger, S.I., Samet, J.M. 2006. Fine particulate air pollution and hospital admission for cardiovascular and respiratory diseases. JAMA, 295:1127-1134.

Hang, Y.C., Lee, J.T., Kim, H., Ha, E.H., Schwartz, J., Christiani, D.C. 2002. Effects of air pollutants on acute stroke mortality. Environ. Health 
Prospect, 110: 187-191.

Karar, K., Gupta, A.K., Kumar, A., Biswas, K.A., Devotta, S. 2006. Statistical interpretation of weekday/weekend differences of ambient particulate matter, vehicular traffic and meteorological parameters in an urban region of Kolkate, India. Indoor Built Environ., 15: 235-245.

Lee, B.K., Hieu, N.T. 2010. Seasonal variation and sources of heavy metals in atmospheric aerosols in a residential area of Ulsan, Korea. Aerosol Air Qual. Res., 11: 679-688.

Mueller, W., Smith, D.L. 1991. Compilation of EPA's sampling analysis methods. N.H. Keith Ed. CNhelsea, M.I. Lewis Publisher National Research Council in human Exposure For Airborne Pollutants. Adv. Opportunities, CLS.
Okwo, J.M., Okolo, P.O. 2011. Levels of $\mathrm{AS}, \mathrm{Pb}, \mathrm{Cd}$ and $\mathrm{Fe}$ in suspended particulate matter (spm) in ambient air in benin city, Nigeria. Bayero J. Pure Appl. Sci., 4(2): 97-99.

U.S., Environmental Protection Agency. 2004. Air quality for particulate matter. Available at http://www.epa.gov./ttn/naaqs/standa rds $/ \mathrm{pm} / \mathrm{s}$ pm. or. ed.html.

Yahaya, N.Z., Sadullah, A.M. 2006. The analysis of total suspended particles (tsp) emitted by the motor vehicle in an urban areas: Kuala Terengganu Case Study. 24-25th July 2006; Putrajaya, Malaysia. Proceedings 1st Int. Con. Nat. Res. Engi. Tech., 322329.

\section{How to cite this article:}

Esekhagbe, R.O., Onwumere' G.B., and Vantsawa'P.A. 2016. Evaluation of Total Suspended Particles in Ambient Air of Small Scale Industries in Kaduna Metropolis. Int.J.Curr.Microbiol.App.Sci. 5(3): 36-41. doi: http://dx.doi.org/10.20546/ijcmas.2016.503.005 